\title{
The Modern Status of the Velikaya River Delta on the State of Primary Producers
}

\author{
Tatiana Drozdenko \\ Pskov State University \\ Pskov,Russia \\ tboichuk@mail.ru
}

\author{
Anna Chernova \\ Pskov State University \\ Pskov,Russia \\ amsty_anna@mail.ru
}

\author{
Sergei Mikhalap \\ Pskov State University \\ Pskov, Russia \\ sgmikhalap@gmail.com
}

\author{
Kristina Mikhailova \\ Pskov Department of the Russian \\ Research Institute of Fisheries and \\ Oceanography (VNIRO) \\ Pskov,Russia \\ kristina.pismo@yandex.ru
}

\begin{abstract}
Primary producers are an integral part of freshwater ecosystems. Phytoplankton forms the basis of the trophic pyramid, participates in the formation of water quality and acts as a sensitive indicator of the state of the reservoir. The ability of macrophytes to accumulate mineral and organic substances makes them active participants in the self-purification of natural waters. Higher aquatic plants are characterized by conservatism to short-term changes in the environment, but changes in vegetation over the years may indicate anthropogenic transformation of ecosystems.

The contribution to maintaining the stability of the functioning and biodiversity of the ecosystem makes phytoplankton and macrophytes compulsory research objects aimed at studying the state of water bodies.

The aim of the work was the study of primary producers as bioindicators of the ecological status of the Velikaya river delta in the summer of 2018.

As a result, 127 phytoplankton taxa from 8 phylums were found: Chlorophyta, Bacillariophyta, Cyanobacteria, Euglenophyta, Chrysophyta, Dinophyta, Cryptophyta, Charophyta. The species richness was dominated by the Chlorophyta (42.5\%), Bacillariophyta (25.2\%), Cyanobacteria (11.1\%). According to the ecological and geographical analysis of the delta algaflora, cosmopolitan, freshwater, planktonic forms of microalgae dominate, preferring neutral and weakly alkaline waters. Water quality assessment revealed the beta-mesosaprobic nature of the waters, which indicates moderate pollution of the water area.
\end{abstract}

In the composition of macrophytes, 43 species from 3 phylums were identified: Magnoliophyta, Equisetophyta, Chlorophyta. By species composition, angiosperms dominated $(95.3 \%)$, of which $46.3 \%$ were dicotyledons and 53.7\% - monocotyledons. Hygrophytes (34.9\%) and hydrophytes $(32.6 \%)$ prevailed in terms of ecological structure. The leading role in the overgrowing of the delta belonged to high-grass helophytes and rooting hydrophytes with leaves floating on the water. A total of 37 saprobiont flora were found. The total index of saprobity was 277 points.

Keywords-algae, ecological assessment, ecological monitoring, phytoplankton, macrophyte, primary producer, Velikaya river delta.

\section{INTRODUCTION}

All ecosystems exist under conditions of constant maintenance of the balance of matter and energy, which are the basis of their long-term existence [1]; [2]; [3]. On an ecosystem scale, most of the energy is provided by the producers in the process of photosynthesis, after which it is used by organisms of next trophic levels. Therefore, regardless of the complexity of the ecosystem, an accurate assessment of the production speed of organic matter is needed so we can understand ecosystems functioning and they thermodynamic behavior [4]; [5].

Aquatic ecosystems are a unique position in the general structure of ecosystems, since they are characterized by a high rate of substance renewal and closer integration of all biotic components. For that reason they are characterized by a quick response to any external disturbances, which allows them to be used as objects for long-term environmental monitoring.

Freshwater ecosystems are characterized by a smaller scale compared to marine ones, enabling them to be used for regional and local environmental monitoring, and the field data help develop predictive ecological models of higher quality. The two most important groups of primary producers of freshwater ecosystems are planktonic algae and macrophytes. They make the greatest contribution to the primary production of aquatic ecosystems and are characterized by specific responses to dynamic processes occurring in the environment. Some authors have suggested, that up to $60-70 \%$ of the primary production in freshwaters of the North-West falls on phytoplankton. The productivity value of phytoplankton determines the abundance of next links in the food chain [6]; [7]. Macrophytes creates a favorable habitat and breeding for many hydrobionts and form heterogeneous habitat conditions, which contributes to an increase in the biodiversity of water bodies.

External factors such as features of the movement of water masses, mineralization, organic pollution, temperature, oxygen concentration and $\mathrm{pH}$ have a 
significant impact on the long-term and seasonal dynamics of primary producers and contribute to the formation of specific responses that can be used to study the state of natural water bodies.

Ecotone ecosystems contain the largest reserves of organic matter, since, apart from their own primary production, they are closely related to the continental ecosystems, from which they receive additional organic matter in the form of effluent, which significantly increases their productivity [8]; [9]; [10]. As a result, ecotone ecosystems function as biogeochemical reactors that supply large areas of waterbodies of organic matter.

The Velikaya river delta (Pskov Region, Russia) is a typical ecotone ecosystem with a high diversity of communities of primary producers. In recent years, the delta is characterized by its increased dynamics of overgrowing by macrophytes, which indicates an abundance of nutrients, in particular phosphorus [11]. This may be due to both external causes and the natural processes in the waterbody. The structure of phytoplankton communities is subject to seasonal and spatial changes, the nature of which is not fully studied [10]; [12]. In this regard, it is necessary to clarify the regional forecasts of the reactions of primary producers to a set of external factors, including those associated with global climate change processes.

The purpose of this work is to study the primary producers of the Velikaya river delta as bioindicators of the ecological state of the water body.

\section{Matherials AND METHODS}

Hydrobiological samples were collected out in the summer period of 2018 in the Velikaya river delta. The results of measuring the parameters of the water showed that the average temperature at the time of sampling was $25.5^{\circ} \mathrm{C}$ and the $\mathrm{pH}$ of the medium was 8.03.

Phytoplankton samples were collected from the surface horizon at five sampling stations (Fig. 1). They are fixed with $40 \%$ formalin and concentrated by the sedimentary method. The samples were processed in a laboratory by standard methods [13].

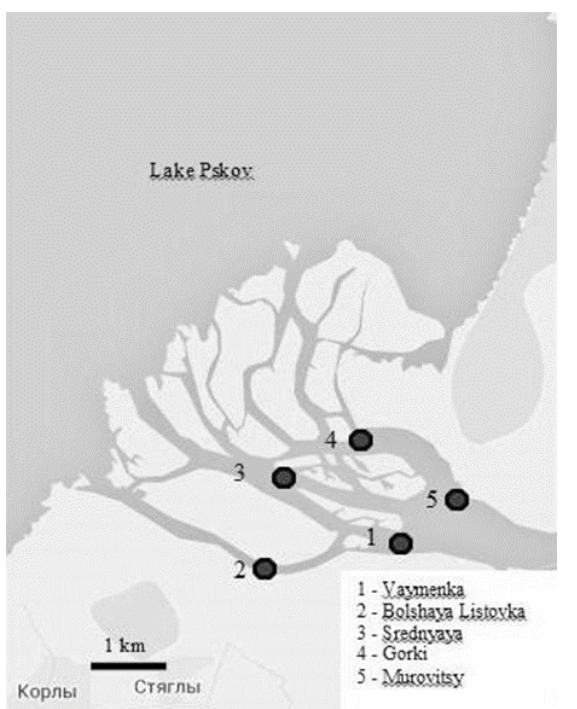

Fig. 1.

The sampling stations in the Velikaya river Delta
Phytoplankton taxonomic identification was performed in the laboratory of Pskov State University using a Carl Zeiss Axio Lab A1 microscope. A number of reference books were used to identify taxones [10]. In the allocation and location of the algae divisions, the system used in the "Algae Handbook" [14] was used. The abundance of phytoplankton was calculated using standard methods [10]. Algae biomass was determined by a standard methods [15]. To clarify the ecological data of algae, a number of monographs were used [16], [17], [18]. The saprobic index was calculated by the method of Pantle and Buck [19]. Water class quality was determined by phytoplankton biomass [20].

Macrophytes were studied using the generally accepted method of geobotanical studies of aquatic vegetation [21]; [22]. Systematic and ecologicalgeographical analyzes of flora were carried out according to the methods described in a number of articles [23]; [9]. In ecological analysis of flora used classification V. G. Papchenkova [9]. As one of the characteristics of the ecological structure, the hydrofit index of flora proposed by B. F. Sviridenko [24] was used:

$$
I_{h d}=\left(\frac{2 A}{B}\right) \quad 1
$$

where: A - number of aquatic species; B - number of all species of the considered flora.

When describing vegetation, the ecologicalphytocenotic classification of plant communities was used [25]. When forming the names of associations, we were guided by the works of IM Raspopov [26] and VG Papchenkov [9].

The main structural indicators (shoot height, shoot diameter, above-ground biomass) of the main edificator of the delta vegetation cover - Phragmites australis (Cav.) Trin. ex. Stend.

The trophic regime of the studied ecotone was established using a list of indicator species of aquatic macrophytes [16]. To assess the trophicity of the aquatic environment, the Tsyganov index (IZ) was calculated in points [27]. This index was calculated by the method of finding the average score based on a list of vascular plant species, in which the averaged tolerance amplitude scores with respect to the generalized salt regime of the soil (trofomorphs) are indicated.

As the source material for the analysis of overgrowth of the Pskov Lake, satellite images of Landsat 5, 7, 8 of different years with minimal cloudiness reflecting the state of coastal aquatic vegetation in the water body were used.

A series of multispectral images of Landsat 5, 7, and 8 satellites was obtained from the data catalog of the US Geological Survey (USGS) for the period from 1988 to 2018 for the area of Pskov Lake. All stages of the preparation of remote sensing data and their processing were carried out in the QGIS 3.4.

As a basic tool for the classification procedure of remote sensing data the SCP module (Semi-Automatic Classification Plugin) for QGIS was used. After selecting the most successful classification and correction option, 
all the images were translated into a vector format, and using the field calculator tool in QGIS, we calculated the area of overgrowth by macrophytes.

\section{RESUlTS AND DISCUSSION}

As a result of a qualitative analysis of phytoplankton in the Velikaya river delta 127 taxa from 7 phylums, 11 classes, 18 orders, 38 families and 76 genera were found.

General analysis of data from all research stations showed that the basis of the flora was 3 phylums: Chlorophyta - 54 (42.5\% of the total number of species), Bacillariophyta - 32 taxons (25.2\%) and Cyanobacteria 14 taxons (11.1\%) (Table 1).

In total, these departments accounted for $77.8 \%$ of phylums, $86.8 \%$ of families and $82.9 \%$ of genera of the total number of detected microalgae taxa. The species richest families were the Scenedesmaceae and Selenastraceae from the green algae, the Naviculaceae and the Fragilariaceae from the diatoms, and the Merismopediaceae from the cyanobacteria.

TABLE 1

TAXONOMIC COMPOSITION OF PHYTOPLANCTON OF THE VELIKAYA RIVER DELTA (SUMMER, 2018)

\begin{tabular}{|c|c|c|c|c|c|c|}
\hline \multirow[b]{2}{*}{ Phylums } & \multirow[b]{2}{*}{$\begin{array}{l}\text { Number } \\
\text { of species } \\
\text { (pc.) }\end{array}$} & \multicolumn{5}{|c|}{ Sample stations } \\
\hline & & 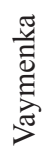 & 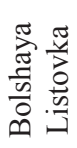 & 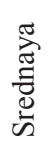 & $\begin{array}{l}\bar{a} \\
\overline{0} \\
0\end{array}$ & 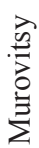 \\
\hline Chlorophyta & 54 & 39 & 29 & 32 & 28 & 37 \\
\hline Bacillariophyta & 32 & 15 & 24 & 15 & 16 & 15 \\
\hline Cyanobacteria & 14 & 12 & 11 & 10 & 6 & 6 \\
\hline Chrysophyta & 8 & 7 & 7 & 7 & 7 & 6 \\
\hline Euglenophyta & 7 & 5 & 6 & 5 & 3 & 2 \\
\hline Dinophyta & 7 & 4 & 4 & 6 & 3 & 2 \\
\hline Cryptophyta & 4 & 4 & 3 & 4 & 2 & 3 \\
\hline Итого & 127 & 86 & 84 & 79 & 65 & 71 \\
\hline
\end{tabular}

The remaining phylums are represented by a small number of species: Chrysophyta - $8(6.3 \%)$, Euglenophyta - 7 (5.5\%), Dinophyta - 7 (5.5\%), Cryptophyta - 4 (3.1\%) (Table 1).

Thus, the taxonomic composition of summer phytoplankton of the Velikaya river delta in 2018 was characterized as green-diatom-cyanobacterial. A similar situation was observed in the summer period of 2015. In the summer season of 2016 and 2017 the first place by the number of taxa were diatoms.

An analysis of the phytoplankton species richness in the sampling stations showed that the largest number of taxa was noted at the stations "Vaymenka" and "Bolshaya Listovka" (86 and 84 taxa, respectively), and the smallest - at the "Gorki" (62). At the stations "Vaymenka" "Bolshaya Listovka" and "Srednaya" green algae, diatoms and cyanobacteria were dominated, at the "Murovitcy" third place in the number of taxa was divided by Cyanobacteria and Chrysophyta, and in the "Gorki" Cyanobacteria dropped out of the dominant complex and gave way to Chrysophyta (Table 1).

The number of phytoplankton varied from 2.7 million cells/l ("Gorki") to 9.9 million cells/1 ("Bolshaya Listovka") (Table 2). The average abundance for all sampling stations was 6.1 million cells/l, of which Cyanobacteria accounted for about 2.8 million cells/1 (45.9\% of the total algae population). The dominant species were representatives of the genera Aphanocapsa Näg., Aphanothece Näg., Merismopedia Meyen., Snowella Kütz. Green algae accounted for 2.2 million cells per liter (36.1\%). At the same time, it should be noted that Binuclearia lauterbornii (Schmidle) at some stations was dominated (10.8-16.2\% of the total). The remaining $18.0 \%$ accounted for the number of representatives of other phylums.

The biomass of planktonic algae ranged from 0.6$1.8 \mathrm{mg} / \mathrm{l}(\mathrm{Bav}=1.2 \mathrm{mg} / \mathrm{l})$. The minimum values of the total biomass are noted at the stations "Gorki" and "Murovytsy", the maximum - at the station. "Vaymenka" (Table 2).

TABLE 2

QUANTITY PARAMETRS OF PHYTOPLANKTON OF THE VELIKAYA RIVER DELTA (SUMMER 2018)

\begin{tabular}{|l|c|c|c|c|c|c|}
\hline \multirow{2}{*}{ Parameters } & \multicolumn{5}{|c|}{ Sample stations } & \multirow{2}{*}{ Mean } \\
\cline { 2 - 7 } & 1 & 2 & 3 & 4 & 5 & \\
\hline $\begin{array}{l}\text { Abundance, million } \\
\text { cell/1 }\end{array}$ & 7.3 & 9.9 & 7.5 & 2.7 & 3.1 & $6.1 \pm 1.4$ \\
\hline Biomass, mg./1 & 1.8 & 1.3 & 1.4 & 0.6 & 0.7 & $1.2 \pm 0.2$ \\
\hline
\end{tabular}

According to phytoplankton biomass, the Velikaya river delta in the summer period of 2018 belonged to the 3 rd class of water quality - the water of satisfactory cleanliness.

Ecological-geographical analysis of phytoplankton showed that the most of the 127 species were the most cosmopolitan by distribution - 88 taxons (69.3\%) (Table 3).

TABLE 3

ECOLOGICAL-GEOGRAPHICAL CHARACTERISTIC OF PHYTOPLANKTON OF THE VELIKAYA RIVER DELTA

\begin{tabular}{|c|c|c|}
\hline Parameters & $\begin{array}{c}\text { Number of } \\
\text { species }\end{array}$ & $\begin{array}{c}\text { Percentage of } \\
\text { total number } \\
\text { species }\end{array}$ \\
\hline \multicolumn{3}{|l|}{ Distribution } \\
\hline cosmopolitans & 88 & 69.3 \\
\hline boreal & 6 & 4.7 \\
\hline galarctic & 5 & 3.9 \\
\hline arctic & 1 & 0.8 \\
\hline no data & 27 & 21.3 \\
\hline \multicolumn{3}{|l|}{ Habitat } \\
\hline planctonic & 75 & 59.1 \\
\hline lanktonic-benthic & 39 & 30.6 \\
\hline benthic & 10 & 7.9 \\
\hline epiphyton & 3 & 2.4 \\
\hline \multicolumn{3}{|l|}{ Halobility } \\
\hline Indifferent & 70 & 55.1 \\
\hline Halophyles & 13 & 10.2 \\
\hline Oligogalobs & 6 & 4.7 \\
\hline Halophobs & 3 & 2.4 \\
\hline no data & 35 & 27.6 \\
\hline \multicolumn{3}{|l|}{ Related to $\mathrm{pH}$} \\
\hline Indifferent & 37 & 29.1 \\
\hline Alcaliphile & 21 & 16.5 \\
\hline
\end{tabular}




\begin{tabular}{|l|c|c|}
\hline Acidophile & 5 & 3.9 \\
\hline Alcalibionts & 2 & 1.6 \\
\hline no data & 62 & 48.9 \\
\hline Saprobity \\
\hline$\beta$ - mezosaprobionts & 49 & 48.6 \\
\hline o- $\beta, \beta$-o- saprobionts & 16 & 15.8 \\
\hline o- $\alpha$ - mezosaprobionts & 11 & 10.9 \\
\hline $\begin{array}{l}\alpha-\beta, \beta-\alpha \text { - mezosapro- } \\
\text { bionts }\end{array}$ & 9 & 8.9 \\
\hline oligosaprobionts & 9 & 8.9 \\
\hline$\alpha$ - mezosaprobionts & 5 & 5.0 \\
\hline$\chi$ - $\beta$ - mezosaprobionts & 1 & 1.0 \\
\hline$\beta$-polisaprobionts & 1 & 1.0 \\
\hline Mean Pantle-Bukk index & & 2.0 \\
\hline
\end{tabular}

By the habitat was dominated by plankton taxa - 75 (59.1\%). Plankton-benthic forms were represented by 39 taxa (30.6\%). A small number of benthic forms and epiphytonic forms were encountered.

In relation to the halobility, all phytoplankton species were freshwater, of which 70 taxa (55.1\%) - indifferent, 13 species $(10.2 \%)$ - halophiles, 3 taxons $(2.4 \%)$ -halophobes.

In relation to the acidity factor, indifferent species prevailed $(29.1 \%)$, in second place were alkaliphils 21 taxa (16.5\%). The other forms accounted for a small percentage. Almost half of the microalgae did not have information about this factor.

A total of 101 saprobity indicator species were found. Most of them were $\beta$-mezosaprobes - 49 (48.6\%). Species preferring pure waters, as well as species preferring polluted waters, accounted for 26 taxa each (Table 3 ).

According to the results obtained no significant changes in the values of the saprobity index have been observed in comparison with results of 1992. (Table 4). The waters of the Velikaya river delta belong to the third quality class - moderately polluted.

TABLE 4

VALUES OF PANTLE-BUKK INDEX IN THE VELIKAYA RIVER DELTA IN DIFFERENT YEARS

\begin{tabular}{|c|c|}
\hline Years & Pantle-Bukk Index value \\
\hline 1992 & $1.9-2.2$ \\
\hline 2000 & $1.7-2.2$ \\
\hline 2001 & $2.3-3.5$ \\
\hline 2016 & $2.0-2.2$ \\
\hline 2018 & $1.8-2.1$ \\
\hline
\end{tabular}

The highest value of the Pantle-Bukk index was noted at "Murovitsy" station - 2.1, the smallest - at "Bolshaya Listovka" station - 1.8. The obtained index values at the research stations are close, which characterizes the delta as a relatively homogeneous territory in terms of organic pollutants concentration in the water.

As a result of studying the flora of vascular aquatic vegetation of the Velikaya river delta in the summer of 2018, 43 species belonging to 3 phylums, 23 families and 36 genera were identified (Table 5).

TABLE 5

TAXA COMPOSITION OF MACROPHYTES OF THE VELIKAYA RIVER DELTA (SUMMER, 2018)

\begin{tabular}{|l|c|c|c|c|}
\hline \multirow{2}{*}{\multicolumn{1}{c|}{ Taxa }} & \multicolumn{3}{c|}{ Number } & $\begin{array}{c}\text { \% of all } \\
\text { species }\end{array}$ \\
\cline { 2 - 4 } & Families & Genera & Species & 2.3 \\
\hline Chlorophyta & 1 & 1 & 1 & 2.3 \\
\hline Equisetophyta & 1 & 1 & 1 & 95.3 \\
\hline Magnoliophyta & 21 & 34 & 41 & 53.7 \\
\hline Liliopsida & 11 & 20 & 22 & 46.3 \\
\hline Magnoliopsida & 10 & 14 & 19 & 49 \\
\hline
\end{tabular}

The species composition was dominated by the Magnoliophyta. The dicotyledonous plants accounted for $46.3 \%$ of the total number of angiosperms, for monocots - 53.7\%. Chlorophyta and Equisetophyta did not contribute significantly to the species richness $-2.3 \%$ each. Among the families prevailing in the number of species were the following: Ranunculaceae (5 species), Poaceae, Hydrocharitaceae, Cyperaceae, Lemnaceae, Nymphaeaceae (3 species each).

According to geographical analysis, the flora of the Velikaya river delta were represented by four regional and five zonal types of areals (Table 6).

TABLE 6

NUMBER SPECIES WITH DIFFERENT TYPES OF AREALS IN THE FLORA OF THE VELIKAYA RIVER DELTA

\begin{tabular}{|c|c|c|c|c|c|}
\hline \multirow{2}{*}{ Regional areal type } & \multicolumn{5}{|c|}{ Zonal areal types } \\
\cline { 2 - 6 } & $\mathrm{p}$ & $\mathrm{asm}$ & $\mathrm{bm}$ & $\mathrm{bsm}$ & Total \\
\hline $\mathrm{Pl}$ & 10 & - & - & - & 10 \\
\hline $\mathrm{H}$ & 10 & 1 & 2 & - & 13 \\
\hline EA & 6 & - & 7 & 1 & 14 \\
\hline ES & - & 1 & 1 & 4 & 6 \\
\hline Total & 26 & 2 & 10 & 5 & 43 \\
\hline
\end{tabular}

Pl - pluriregional, H - Holarctic, EA - Euro-Asia, ES - Euro-Seberia; $\mathrm{p}$ - plurizonal, asm - arctic-submeridian, bm - boreal-meridian, bsm boreal-submeridional.

The most numerous were the macrophytes of four types of areas: the pluriregional pluurizonal, the holarctic plurizonal - 10 species (23\%), the Eurasian borealmeridional - 7 species (16\%) and the Eurasian plurizonal - 6 species $(14 \%)$.

Thus, the flora of the ecotone was dominated by species widely distributed in different zones and regions - Plurizonal, Holarctic, and Eurasian.

The ecological structure of the flora of the Velikaya river delta was represented by four ecotypes: hygrophytes, hydrophytes, helophytes and hygrohelophytes. Coastal (near-water) plants and hydrophytes - real aquatic plants (32.6\%) prevailed.

The following ecological groups dominated among hydrophytes: 1 - hydrophytes freely floating in the water column (Lemna spp., Stratiotes aloides L.); 2 - submerged rooting hydrophytes (all Potamogeton species, Batrachium circinatum (Sibth.) Spach, Elodea Canadensis Michaux, etc.), 3 - rooting hydrophytes with floating leaves (Nuphar lutea (L.) Smith and N. pumila (Timm) DC, Nymphaea candida JC Presl.).

Helophytes, or air-aquatic plants (23.3\%), are equally represented by tall grass plants - Phragmites australis (Cav). Trin. ExSteud, Typha angustifolia L., Glyceria 
mixima (Hartm.) Holmb, Scirpus lacustris (L.) Palla and others, and low-grass plants - Butomus umbellatus L., Equisetum fluviatile L., Sagittaria sagittifolia L. and others.

Hygrogelophytes (near-water plants) accounted for $9.3 \%$ of the total number of macrophyte.

In general, the diversity of the water flora is slightly lower than the coastal waters flora, which is also indicated by the hydrophyte index equal to -0.35 .

Analysis of the taxonomic structure of communities indicated a wide variety of macrophyte communities in the Velikaya river delta. In total, 26 associations belonging to three classes of formations, five groups of formations and 16 formations were identified.

Aquatic vegetation (Aquiphytosa genuine) is represented by three groups of formations and eight associations. The communities of rooting hydrophytes with leaves floating on the surface of the water prevailed (three formations).

In the group of classes coastal aquatic vegetation (Aquiherbosa vadosa) was dominated by a group of highgrass helophyte - formations (Aquiherbosa helophyta procera) - $38 \%$ of the total number of associations. The main ecosystem engineer species this type were Phragmites australis, Scirpus lacustris L. and Typha angustifolia $\mathrm{L}$.

Leading role in the overgrowing of the Velikaya river delta was belonged to the high-grass helophytes and the rooted hydrophytes with floating leaves. Helophytes formed mono- and multi-component communities that located on coasts of numerous islands in the delta. In this they formed a strip from 2 to $20 \mathrm{~m}$ wide. The river channels between the islands were overgrown with groups of Nuphar lutea, N. pumila, Nymphaea candida.

Reed beds were spread along the entire coastline, and were surround numerous islands and well as common in the form of separate spots in channels of the delta.

The most common in the lake are clean (one-species) reed beds.

The average height of the reed was $259.7 \pm 5.30 \mathrm{~cm}$, stem diameter $0.78 \pm 0.04 \mathrm{~cm}$. The aboveground biomass varied between 954.0-1877.0 $\mathrm{g} / \mathrm{m}^{2}$.

According to saprobiological analysis, 24 saprobiont of the flora were found $(55.8 \%$ of the total number of species). B-mesosaprobes were dominated $-37.5 \%$. The share of oligosaprobes and $\beta-\alpha, \alpha-\beta$ - saprobionts were accounted for $12 \%$ each.

Whole 37 trofomorphs with a known trophic score in the composition of the flora of the Velikaya river delta were revealed. Species with a high trophic index (8-10 score) - 21 (57\%). According to the Tsyganov Index (IZ), the total trophic grade point of the aquatic environment was 277 score.

\section{Conclusions}

Thus, the species composition of phytoplankton of the Velikaya river delta in summer of 2018 as green-diatomcyanobacterial was characterized.

The average phytoplankton abundance was 6.1 million cells/l., mean biomass - $1.2 \mathrm{mg} / \mathrm{l}$.

According to the ecological and geographical analysis in the Velikaya river delta freshwater, widespread, planktonic microalgae, preferring slightly alkaline waters were prevailed.

According to the saprobiological analysis of the delta's waters to the 3rd class of quality were classified. The average index of saprobity in Pantle-Bucca was 2.0.

In the aquatic vascular vegetation of the delta, 26 associations belonging to 3 classes of formations, 5 groups of formations and 16 formations were identified.

In the flora by the Magnoliophyta was dominated. Plurizonal, holarctic and eurasian geographical elements were prevailed. The hydrophilic core of the flora (hydrophytes, helophytes and hygrohelophytes) was $65 \%$.

Main role in the overgrowing of the Velikaya river delta to the high-grass helophytes was belonged. Phragmites australis was the main ecosystem engineer.

Among the 37 saprobionts of the flora, $\beta$-mesosaprobes - indicators of moderate water pollution were dominated.

\section{REFERENCES}

[1] E. P. Odum. Fundamentals of Ecology. Saunders, Philadelphia. 1971.

[2] M. Begon, , J.L. Harper \& C.R. Townsend. Ecology: Individuals, Populations and Communities, 3rd edn. Blackwell, London. 1996.

[3] Howarth, R.W., \& Michaels, A.F. The Measurement of Primary Production in Aquatic Ecosystems. Methods in Ecosystem Science. 2000, pp. 72-85. DOI:10.1007/978-1-4612-1224-9_6 [Accessed January 24, 2019].

[4] W.R. Boynton, , W.M. Kemp and C.W. Keefe.: A comparative analysis of nutrients and other factors influencing estuarine phytoplankton production, in: Estuarine Comparisons, edited by: Kennedy, V. S., Academic Press, New York, 1982.

[5] Ajayan K.V. and Parameswara Naik T. Phytoplankton Primary Productivity in Lentic Water Bodies of Bhadravathi Taluk, Shimoga District, Karnataka, India. International Research Journal of Environment Sciences. Vol. 3(4),. 2014, pp. 34-41.

[6] Methods of studying the biogeocenoses of inland waters. / F.D. Mordukhay-Boltovsky editor. Moscow. Nauka. 1975.

[7] M.V. Kolchenko, T.V. Drozdenko, S.G. Mikhalap. Features of phytoperiphyton of reed of the great river delta // Water: chemistry and ecology. № 5 (95). 2016, pp. 19-26.

[8] Hopkinson, C. J., Smith, E. M., del Giorgio, P. A., and P. J. le B. Williams,: Estuarine respiration: an overview of benthic, pelagic and whole system respiration, in: Respiration in Aquatic Ecosystems, edited by: del Giorgio, P. A. and Williams, P. J. le B., Oxford University Press, New York, 2005.

[9] V.G. Papchenkov. Vegetative cover of reservoirs and watercourses of the Middle Volga region. Yaroslavl, 2001.

[10] T. Drozdenko, S. Mikhalap, L. Nikolskaya, A. Chernova. Assessment of Ecological State of the Velikaya River Delta Based on Hydrochemical Indicators and Structure of Phytoplankton / Environment. Technology. Resources: Proceeding of the $11^{\text {th }}$ International Scientific and Practical Conference.. Volume 1. Rezekne: Rezekne Academy of Technologies, June 15-17, 2017, pp. 82-88.

[11] J. Haberman, M. Haldna, R. Laugaste, K. Blank. Recent changes in large and shallow Lake Peipsi (Estonia/Russia): Causes and consequences. Polish Journal of Ecology. 2010. 58(4), pp. 645662.

[12] T.V.Drozdenko, S.G. Mikhalap. Structural-taxonomic diversity and ecological features of the phytoplankton of the Velikaya river delta (Pskov Region). Tomsk State University Journal of Biology. 41. 2018. pp. 118-134.

[13] V.D. Fedorov. On the methods of studying phytoplankton and its activity / VD Fedorov. M.: Moscow State University Publishing House, 1979.

[14] Algae: a reference book / S.P. Wasser, N.V. Kondratieff, N.P. 
Masyuk Handbook / S. P. Vasser, N. V. Kondratieva, N. P. Masyuk, G. M. Palamar-Mordvintseva, Z. I. Vetrova, E. L. Kordyum, N. A. Moshkova, L. P Prikhodkova, O. V. Kovalenko, V. V. Stupina, P. M. Tsarenko, V. P. Jünger, M. I. Radchenko, O. N. Vinogradova, L. N. Bukhtiyarova, L. F. Razumna / Vasser S. P., Kondratieva N. V., Masyuk N. P., et al. editor. Kiev: Nauk. Dumka, 1989.

[15] K.A. Guseva. On the phytoplankton accounting methodology, Works of the Institute Biology reservoirs. Vol. 2. Spb. 1959, pp. 44-51.

[16] S.S.Barinova, A.L. Medvedeva, O.V. Anisimova Biodiversity of algae-indicators of the environment. Tel Aviv. 2006.

[17] D.N. Sudnitsyna. Ecology of Algae of the Pskov Region. Tutorial. Pskov: PSPU. 2005.

[18] D.N. Sudnitsyna. Algoflora reservoirs of the Pskov region. Pskov: LOGOS Plus LLC, 2012.

[19] Pantle F., Buck H. Die biologischeÜberwachung der Gewässer und die Darstellung der Ergebnisse // Gas - und Wasserfach, 1955. Bd 96, № 18, pp.. 604-618.

[20] O.P. Oksiyuk, V.N. Zhukinsky, L.P. Braginsky ,P.N. Linnik, M.I.
Kuzmenko, V.G. Klenus. Integrated ecological classification of surface water quality in the land // Hydrobiological journal. Vol. 4. 1993, pp. 62-76.

[21] V.M. Katanskaya. Higher aquatic vegetation of continental waters of the USSR. Leningrad, 1981.

[22] A.P. Belavskaya. Aquatic plants of Russia and neighboring states. St. Petersburg., 1994.

[23] B.A. Yurtsev , R.V. Kamelin. Basic concepts and terms of floristics. Perm press, 1991.

[24] B.F. Sviridenko The structure of the aquatic flora of the North Caucasus. Botanical Journal. Vol. 82. 1997, pp. 47-56.

[25] V.I. Vasilevich. Is Ecological-phytocenotic or floristic classification of vegetation? Hydrobotics: methodology, methods: Mater. Schools on hydrobotany. Borok, April 8-12, 2003. Rybinsk, 2003. pp. 118-125.

[26] Raspopov I.M. Higher aquatic vegetation of large lakes of the North-West of the USSR. Leningrad, 1985.

[27] D.N. Tsyganov Phytoindication of ecological regimes in the subzone of coniferous-deciduous forests. Moscow, Nauka. 1983. 